\title{
Origen y efectos deteriorantes del yeso en monumentos graníticos del noroeste de España
}

\author{
Gypsum-induced decay in granite monuments \\ in Northwestern Spain
}

\author{
B. Silva Hermo ${ }^{(*)}$, B. Prieto Lamas(*), T. Rivas Brea(**), L. Pereira Pardo(*)
}

Recepción/Received: 3-II-08

Aceptación/Accepted: 9-XII-08

Publicado online/Online publishing: 4-III-10

\section{RESUMEN}

Una de las formas de deterioro más frecuente en los monumentos graníticos es la separación de la capa superficial de la piedra (placas, plaquetas y escamas). En trabajos anteriores centrados en monumentos del noroeste de la Península Ibérica, se constató la relación directa entre esta forma de alteración y la presencia de sulfato de calcio y se propuso el mecanismo a través del cual esta sal provoca este tipo de deterioro. En este trabajo se plantean varias hipótesis acerca del origen del yeso encontrado en monumentos graníticos. Para ello se comparan los contenidos de iones solubilizados en agua, los resultados de difracción de rayos $\mathrm{X}$ y las relaciones $\mathrm{OCa} / \mathrm{SO}_{3}$ de muestras de piedra, morteros y depósitos recogidas en diferentes monumentos. Se llega a la conclusión de que en la mayor parte de los casos el yeso procede de antiguas pinturas o de revestimientos superficiales y de los morteros de juntas entre sillares, pero no se puede descartar la contribución de otros aportes, los cuales se discuten también en este artículo.

Palabras clave: monumentos, granito, yeso, placas, deterioro de la piedra.

\section{SUMMARY}

One of the most common forms of decay in granite monuments is the detachment of the superficial layer of the stone (plaques, plaquettes and scales). Previous studies of granite monuments in the northwest Iberian Peninsula revealed a direct relation between this type of weathering and the presence of calcium sulphate, and a mechanism whereby the salt causes this type of decay was suggested. In the present study, various hypotheses as regards the origin of the gypsum found in granite monuments are proposed. The study involved analysis of the contents of ions soluble in water, the results of $X$-ray diffraction analyses and the ratios of $\mathrm{CaO} / \mathrm{SO}_{3}$ in samples of stone, mortar and deposits collected from different monuments. It was concluded that in most cases the gypsum originated from old paintworks or plasters and from the joint mortars, although inputs from other sources cannot be discounted, as discussed.

Keywords: monuments, granite, gypsum, plaque shedding, stone decay

\footnotetext{
(*) Universidad de Santiago de Compostela (Santiago, España).

(**) Universidad de Vigo (Vigo, España).
} 


\section{INTRODUCCIÓN}

Las sales solubles son uno de los principales agentes de alteración de las rocas, tanto en el medio natural como cuando éstas forman parte de una estructura arquitectónica (1-3); en este último caso constituyen un grave problema para la conservación del patrimonio monumental construido, siendo numerosas las investigaciones sobre los mecanismos a través de los cuales las sales provocan el deterioro de la piedra (4-6).

Entre los diferentes materiales rocosos utilizados en construcción, los granitos son especialmente susceptibles a la acción de las sales solubles (7-10), compuestos ajenos a estas rocas que penetran en los muros por diferentes vías (2-3). En el caso de los edificios graníticos, las sales provocan dos formas de alteración muy graves $(9,11)$ : la desagregación granular o arenización y la desplacación o separación de la capa más superficial de la piedra paralelamente a la cara externa de los sillares. Las separaciones superficiales pueden tener diferentes dimensiones clasificándose en: placas, cuando la capa de piedra separada tiene un grosor de $5 \mathrm{~mm}$ o más y abarca una extensión grande, a veces toda la superficie del sillar; plaquetas, que son capas igualmente extensas pero de menos de $5 \mathrm{~mm}$ de grueso, y escamas, separaciones finas, de escasa extensión y frecuentemente superpuestas unas a otras.

La observación, estudio y análisis de muestras de numerosos monumentos graníticos en el Noroeste peninsular (Galicia y norte de Portugal) afectados por estas dos formas de deterioro, ha dado como resultado un profundo conocimiento de los mecanismos que generan ambas patologías (11-13), constatándose la gran influencia que tienen las condiciones microclimáticas de las paredes en la aparición de una u otra forma de alteración, puesto que la cristalización de las diferentes sales depende de la temperatura y humedad de los muros.

En el caso de las separaciones superficiales, se encontró que la sal implicada es el sulfato de calcio (11). El origen del yeso, que aparece frecuentemente formando costras, depósitos o eflorescencias en monumentos construidos con calizas o mármoles, es bien conocido: el calcio es aportado por la roca a través de fenómenos de disolución y el sulfato puede proceder de impurezas de la propia roca o, y sobre todo, de la deposición de contaminantes atmosféricos de naturaleza azufrada (3).

En el caso de monumentos graníticos, la presencia de yeso en una roca pobre en calcio y en ambientes con bajos niveles de contaminación (como es el caso de los ambientes en que se encuentran la mayoría de los monumentos estudiados) señala la posibilidad de otras fuentes de esta sal distintas a la deposición atmosférica, que deben ser investigadas.

\section{INTRODUCTION}

Soluble salts are one of the main agents of stone weathering, both in the natural outcrops and when they form part of architectural structures (1-3); in the latter case they constitute a serious problem as regards the conservation of the monumental heritage and numerous studies have been carried out to try to determine the mechanisms whereby salts cause deterioration of stone (4-6).

Among the different materials used in construction, granites are particularly susceptible to the action of soluble salts (7-10), compounds unrelated to the stone and that penetrate walls by different routes (2-3). In the case of granite buildings, salts cause two severe forms of weathering (9, 11): granular disaggregation and the detachment of the surface layer parallel to the outer face of ashlars. Superficial detachments of different sizes occur and can be categorised as: plaques, extensive detached layers of thickness $5 \mathrm{~mm}$ or more, which may extend over the entire surface of the ashlar; plaquettes, which are also extensive but less than $5 \mathrm{~mm}$ thick, and scales, small, thin detachments, often superimposed on one another.

The observation, study and analysis of samples from numerous granite monuments in the northwest Iberian Peninsula (Galicia and northern Portugal) have resulted in a detailed knowledge of the mechanisms that generate both decay forms (11-13), and have demonstrated the great importance of microclimatic conditions in the appearance of one or other type of weathering, as crystallization of the different salts depends on the temperature and humidity of the walls.

In the case of plaque shedding, it has been found that the salt involved is calcium sulphate (gypsum) (11). The origin of the gypsum, which often forms crusts, deposits or efflorescences in monuments made from limestone or marble, is well known: the calcium comes from the stone via dissolution processes and the sulphate may originate from impurities in the stone, or more commonly from the deposition of atmospheric contaminants of sulphuric nature (3).

In the case of granite monuments, the presence of gypsum in stone that does not contain large mounts of calcium and in environments with low levels of contaminants (as where most of the monuments under study are located) indicates the possibility of sources of this salt other than atmospheric deposition. This requires further investigation. 
En este trabajo, a partir de los datos aportados por el estudio de numerosos monumentos graníticos representativos que presentan separaciones superficiales, se plantean varias hipótesis para explicar el origen del yeso.

\section{MATERIAL Y MÉTODOS}

En este artículo se presentan los resultados obtenidos a partir de muestras tomadas en cuatro edificios graníticos de Galicia; tres están situados en Santiago de Compostela: la Catedral, la iglesia de Santa María Salomé y el monasterio de San Martín Pinario, y el cuarto monumento es la basílica de Santa María la Mayor de Pontevedra, situada en el casco histórico de esta ciudad. Todos estos edificios presentan en alguna de sus paredes separaciones superficiales, además de desagregación arenosa y, en menor medida, depósitos salinos.

Se tomaron los siguientes tipos de muestras según los casos:

- Separaciones superficiales a diferentes alturas en las paredes afectadas por esta forma de alteración.

- Arena desprendida de las áreas donde el granito presentaba desagregación granular.

- Pequeños fragmentos rocosos extraídos a diferentes profundidades por debajo de la capa superficial desprendida.

- Depósitos superficiales.

- Morteros de juntas y, en un caso, argamasa de la parte de atrás de un sillar que fue extraído de un muro.

Sobre estas muestras se llevaron a cabo los siguientes análisis:

- Composición mineralógica por difracción de rayos $\mathrm{X}$, a partir de muestras preparadas en forma de polvo cristalino.

- Contenido de sales solubles. Se obtuvieron extractos acuosos de las muestras, finamente disgregadas, por agitación en agua desionizada durante dos horas y posterior filtrado a través de filtros de 45 micras de tamaño de poro. Los aniones solubilizados se cuantificaron por cromatografía iónica y los cationes por espectrometría de absorción o de emisión atómica.

- Estudio con microscopio electrónico de barrido (MEB) y análisis elemental con la microsonda de rayos $\mathrm{X}$ por dispersión de energías (EDAX) acoplada al microscopio.

- Porcentaje de OCa y $\mathrm{SO}_{3}$ de las muestras de morteros. Las muestras se disolvieron en $\mathrm{HCl} 12 \mathrm{~N}$, se separó el residuo insoluble y en el filtrado se determinó el $\mathrm{Ca}$ (que se expresa como OCa) por espectrometría de absorción atómica y el $\mathrm{SO}_{4}{ }^{-2}$ (expresado como $\mathrm{SO}_{3}$ ) por gravimetría.
In this study, various hypotheses are proposed to explain the origin of the gypsum in monuments, from the data obtained from the study of numerous representative granite monuments with superficial detachments.

\section{MATERIAL AND METHODS}

In this study we present the results obtained from samples taken from four granite buildings in Galicia; three in Santiago de Compostela: the Cathedral, the church of St. Maria Salomé and the monastery of S. Martín Pinario, and one in the historical part of the city of Pontevedra: the church of Sta. María la Mayor. All of these buildings have superficial detachments on their walls, as well as sandy disaggregation and to a lesser extent, saline deposits.

The following types of samples were collected, depending on each case:

- Superficial detachments at different heights on walls affected by this form of decay.

- Granitic sand from the areas affected by granular disaggregation.

- Small fragments of stone extracted at different depths underneath the superficial detachments.

- Superficial deposits.

- Joint mortar, and in one case mortar from the back of an ashlar extracted from a wall.

The samples were subjected to the following analyses:

- Mineralogical composition by X-ray diffraction analysis of samples by the random powder method.

- Soluble salt content. Aqueous extracts were obtained by shaking the finely disaggregated samples in deionized water for two hours and then filtering the mixture through $45 \mu \mathrm{m}$ filters. The dissolved anions were quantified by ion chromatography, and the cations by atomic absorption spectrophotometry or atomic emission spectrometry.

- Study by scanning electron microscopy (SEM) and element analysis by energy dispersive $X$-ray analysis (EDAX) with a microprobe fitted to the microscope.

- Percentage of $\mathrm{CaO}$ and $\mathrm{SO}_{3}$ in some mortar samples. The samples were dissolved in $12 \mathrm{~N} \mathrm{HCl}$, the insoluble residue was separated and the filtrate was used to determine the amount of $\mathrm{Ca}$ (expressed as $\mathrm{CaO}$ ) by atomic absorption spectrometry and the amount of $\mathrm{SO}_{4}^{-2}$ (expressed as $\mathrm{SO}_{3}$ ) by gravimetry. 


\section{RESULTADOS}

La catedral de Santiago de Compostela, el más emblemático monumento de la ciudad, es un complejo edificio construido entre los siglos XII y XVIII, lo que explica la variedad de estilos y los diferentes estados de conservación que presenta y da una idea de la cantidad de intervenciones de conservación no documentadas que pudo haber sufrido en el pasado.

Varios de sus muros poseen diversos tipos de separaciones superficiales (14). Los datos presentados en este trabajo corresponden a una de las paredes orientadas hacia el sur y que da a la Plaza de la Quintana. En esta pared se tomaron tres muestras de plaquetas a diferentes alturas y dos muestras de morteros de juntas entre sillares.

Los análisis de los extractos acuosos de las muestras de plaquetas (Tabla 1 ) revelaron que su contenido de sales solubles es bastante alto, siendo los aniones mayoritarios el sulfato y el nitrato y el catión más abundante el calcio. Es frecuente encontrar contenidos altos de nitratos en las partes inferiores de los edificios lo que se explica por el ascenso capilar de disoluciones procedentes del suelo, donde los nitratos se generan por descomposición de la materia orgánica (2-3). Un análisis de correlación lineal entre los iones determinados en estas muestras revela una correlación muy buena entre los iones $\mathrm{Ca}^{2+}$ y $\mathrm{SO}_{4}{ }^{2-}(\mathrm{r}=0,96$ para $\mathrm{p}<0,05)$ lo cual hace pensar que se encuentran combinados. Efectivamente, mediante difracción de rayos X (Tabla 2) se identificó yeso en todas las muestras de plaquetas en una proporción notable, especialmente en la muestra tomada a 70 $\mathrm{cm}$ de altura. También con el MEB se reconocieron los típicos cristales monoclínicos del yeso dentro de los huecos de la roca (Figura 1). Este hallazgo viene a corroborar lo encontrado en trabajos anteriores: entre todos los iones identificados en muestras de separaciones superficiales y en las condiciones bajo las que se encuentra la roca en esta pared, el yeso (que posee una solubilidad moderada) es la sal con más probabilidades de cristalizar, mientras que otras sales más solubles que podrían formarse a partir de los iones presentes, permanecen disueltas.

En los análisis por difracción de rayos $\mathrm{X}$ de las muestras de mortero (Tabla 2) se identificaron los minerales mayoritarios del granito (cuarzo, feldespato y micas), lo que indica que el árido es una arena granítica, trazas de caolinita, la cual probablemente proviene de la alteración de algunos granos de feldespato presentes en la arena, calcita como principal componente del aglomerante, y una cantidad apreciable de yeso, particularmente en el mortero $n^{\circ} 2$. El carácter no cuantitativo de esta determinación no permitió conocer el porcentaje

\section{RESULTS}

The Cathedral of Santiago de Compostela, the most emblematic monument in the city, is a complex building constructed between the XII and XVIII centuries, which explains the variety of styles and the different states of conservation of the building and gives an idea of the great number of undocumented conservation interventions to which the building may have been subjected in the past.

Several of the walls are affected by plaque shedding (14). The data presented in this study correspond to one of the south-facing walls, in the Plaza de la Quintana. Three samples of plaquettes were collected from different heights on the wall and two samples of joint mortar were taken from between ashlars.

Analysis of the aqueous extracts of the plaquette samples (Table 1) revealed a rather high content of soluble salts; the most abundant anions were sulphate and nitrate, and the most abundant cation, calcium. High contents of nitrates are commonly found on the lower parts of buildings, due to capillary rise of solutions originating from the soil, where nitrates are generated by the decomposition of organic matter (2-3). Linear correlation analysis of the ions quantified in these samples revealed a good correlation between $\mathrm{Ca}^{2+}$ and $\mathrm{SO}_{4}{ }^{2-}(r=0.96, p<0.05)$, which may indicate that these ions are combined. Indeed the $X$-ray diffraction analysis (Table 2) revealed a high proportion of gypsum in all of the plaquette samples, especially in the sample taken from a height of $70 \mathrm{~cm}$. The typical monoclinic crystals of gypsum were also identified within the rock fissures, by SEM (Figure 1). This finding corroborates the results of previous studies: amongst all of the ions identified in samples of superficial detachments and under the conditions of the stone in this wall, gypsum (which is moderately soluble) is the salt most likely to crystallize, whereas other more soluble salts that may be formed from the ions present remain in solution.

The X-ray diffraction analysis of the mortar samples (Table 2) revealed the predominant granite minerals (quartz, feldspar and micas), which indicates that the aggregate is a granitic sand, traces of kaolinite, which probably originates from the weathering of feldspar grains present in the sand, calcite as the main component of the binder, and an appreciable quantity of gypsum, particularly in mortar no 2. This analysis was non quantitative and thus does not indicate the percentage of gypsum present, but the low value of the 
Tabla 1 / Table 1

Concentración de iones (\% p/p) en los extractos acuosos. Ion concentration $(\% \mathrm{w} / \mathrm{w})$ in aqueous extracts.

\begin{tabular}{|c|c|c|c|c|c|c|c|}
\hline Muestra/Sample & $\mathrm{SO}_{4}^{2-}$ & $\mathrm{Cl}^{-}$ & $\mathrm{NO}_{3}^{-}$ & $\mathrm{Na}^{+}$ & $\mathbf{K}^{+}$ & $\mathrm{Ca}^{2+}$ & $\mathrm{Mg}^{2+}$ \\
\hline \multicolumn{8}{|c|}{ Catedral de Santiago / Santiago Cathedral } \\
\hline Placa / Plaques $1(40 \mathrm{~cm})$ & 0.573 & 0.264 & 0.750 & 0.126 & 0.080 & 0.373 & 0.004 \\
\hline Placa / Plaques $2(70 \mathrm{~cm})$ & 1.386 & 0.210 & 0.902 & 0.090 & 0.191 & 0.816 & 0.004 \\
\hline Placa / Plaques $3(105 \mathrm{~cm})$ & 0.586 & 0.230 & 1.135 & 0.101 & 0.208 & 0.550 & 0.002 \\
\hline \multicolumn{8}{|c|}{ Iglesia de Salomé / Salomé Church } \\
\hline Plateta / Plaquettes $1(70 \mathrm{~cm})(0-5 \mathrm{~mm}$ depth $)$ & 1.236 & 0.003 & 0.002 & 0.005 & 0.008 & 0.566 & 0.003 \\
\hline Plateta / Plaquettes $1(70 \mathrm{~cm})(5-13 \mathrm{~mm}$ depth $)$ & 3.051 & 0.006 & 0.010 & 0.008 & 0.008 & 1.000 & 0.002 \\
\hline Plateta / Plaquettes 1 (70 cm) (13-17 mm depth) & 0.353 & 0.001 & 0.010 & 0.006 & 0.008 & 0.180 & 0.003 \\
\hline \begin{tabular}{|c|} 
Plateta / Plaquettes $2(80 \mathrm{~cm})$ \\
\end{tabular} & 0.906 & 0.121 & 1.365 & 0.073 & 0.030 & 0.340 & 0.002 \\
\hline Plateta / Plaquettes $3(140 \mathrm{~cm})$ & 1.513 & 0.400 & 1.567 & 0.333 & 0.213 & 0.893 & 0.013 \\
\hline Plateta / Plaquettes $4(150 \mathrm{~cm})$ & 0.406 & 0.034 & 4.124 & 0.019 & 0.019 & 0.100 & 0.001 \\
\hline Mortero / Mortar 1 & 4.180 & 0.180 & 0.540 & 0.070 & 0.050 & 1.000 & 0.000 \\
\hline Mortero / Mortar 2 & 1.950 & 0.250 & 0.490 & 0.070 & 0.020 & 0.920 & 0.000 \\
\hline \multicolumn{8}{|c|}{ Monasterio de S. Martín Pinario / S. Martin Pinario Monastery } \\
\hline Placa / Plaques $1(15 \mathrm{~cm})$ & 1.129 & 0.070 & 0.065 & 0.164 & 0.141 & 0.944 & 0.027 \\
\hline Placa / Plaques $2(45 \mathrm{~cm})$ & 0.780 & 0.087 & 0.067 & 0.099 & 0.198 & 0.693. & 0.027 \\
\hline Placa / Plaques $3(85 \mathrm{~cm})$ & 0.314 & 0.054 & 0.058 & 0.071 & 0.104 & 0.768 & 0.003 \\
\hline Placa / Plaques $4(130 \mathrm{~cm})$ & 0.312 & 0.178 & 0.612 & 0.083 & 0.001 & 0.122 & 0.018 \\
\hline Placa / Plaques 5 (38 cm) (0-3 mm depth) & 1.080 & 0.030 & 0.084 & 0.159 & 0.084 & 1.195 & 0.028 \\
\hline Placa / Plaques 5 (38 cm) (3-9 mm depth) & 0.492 & 0.084 & 0.033 & 0.129 & 0.141 & 0.485 & 0.024 \\
\hline Placa / Plaques 5 (38 cm) (9-15 mm depth) & 0.145 & 0.039 & 0.028 & 0.059 & 0.069 & 0.079 & 0.002 \\
\hline Placa / Plaques 5 (38 cm) (15-21 mm depth) & 0.097 & 0.055 & 0.032 & 0.076 & 0.116 & 0.059 & 0.002 \\
\hline Mortero / Mortar 1 & 0.045 & 0.286 & 0.129 & 0.040 & 0.034 & 0.016 & 0.003 \\
\hline Mortero / Mortar 2 & 0.936 & 0.000 & 0.000 & 0.000 & 0.000 & 0.454 & 0.000 \\
\hline \multicolumn{8}{|c|}{ Iglesia de S. Martín. Pinario / S. Martin Pinario Church } \\
\hline Placa / Plaques 1 & 1.103 & 0.064 & 0.080 & 0.000 & 0.017 & 0.045 & 0.001 \\
\hline Placa / Plaques 2 & 0.345 & 0.039 & 0.003 & 0.093 & 0.015 & 0.015 & 0.001 \\
\hline Esacamas / Scales 1 & 1.845 & 0.317 & 0.378 & 0.005 & 0.147 & 0.289 & 0.004 \\
\hline Escamas / Scales 2 & 9.899 & 0.347 & 0.412 & 0.000 & 0.069 & 0.178 & 0.007 \\
\hline Mortero / Mortar & 0.139 & 0.402 & 0.350 & 0.006 & 0.037 & 0.040 & 0.005 \\
\hline \multicolumn{8}{|c|}{ Sta. María de Pontevedra / Sta María Basilica, Pontevedra } \\
\hline Arena / Sand 1 & 0.049 & 0.047 & 0.085 & 0.029 & 0.048 & 0.065 & 0.004 \\
\hline Arena / Sand 2 & 0.165 & 0.035 & 0.072 & 0.030 & 0.060 & 0.026 & 0.011 \\
\hline Mortero / Mortar 1 & 0.624 & 0.541 & 1.155 & 0.818 & 0.202 & 0.094 & 0.008 \\
\hline Mortero / Mortar 2 & 0.270 & 0.125 & 0.702 & 0.075 & 0.072 & 0.222 & 0.010 \\
\hline Depósito / Deposit 1 & 26.658 & 0.889 & 3.572 & 0.286 & 0.125 & 5.137 & 0.049 \\
\hline Depósito / Deposit 2 & 2.092 & 0.427 & 1.648 & 0.141 & 0.116 & 0.600 & 0.023 \\
\hline Depósito / Deposit 3 & 4.256 & 0.683 & 3.415 & 0.319 & 0.500 & 1.615 & 0.053 \\
\hline
\end{tabular}

de yeso presente, pero del bajo valor de la relación $\mathrm{OCa} / \mathrm{SO}_{3}$ se deduce que, al menos en la muestra $\mathrm{n}^{\circ} 2$, la proporción de este mineral es importante. Hay que tener en cuenta que en el yeso la relación $\mathrm{OCa} / \mathrm{SO}_{3}$ es de aproximadamente la unidad mientras en las cales aéreas adquiere valores muy elevados, puesto que el $\mathrm{SO}_{3}$ constituye sólo una impureza. De estos resultados deducimos que el yeso en estos morteros no es una impureza de la cal ni se ha producido por sulfatación de la misma, si no que, con toda probabilidad, es un constituyente que se añadió a la argamasa en el momento de su preparación. Se trata por tanto de morteros mixtos o bastardos. ratio between $\mathrm{CaO}$ and $\mathrm{SO}_{3}$ indicates that, at least in sample no 2, there was a large proportion of this mineral. It must be taken into account that the $\mathrm{CaO} / \mathrm{SO}_{3}$ ratio in gypsum is approximately one, whereas in aerial lime the value of this ratio is very high, as gypsum is only present as an impurity. From these results we deduce that the gypsum in the mortars is not an impurity of the lime nor has it been produced by sulphatation of the lime, but rather that, it was probably a constituent added during preparation of the mortars. The mortars are therefore mixed or bastard mortars. 


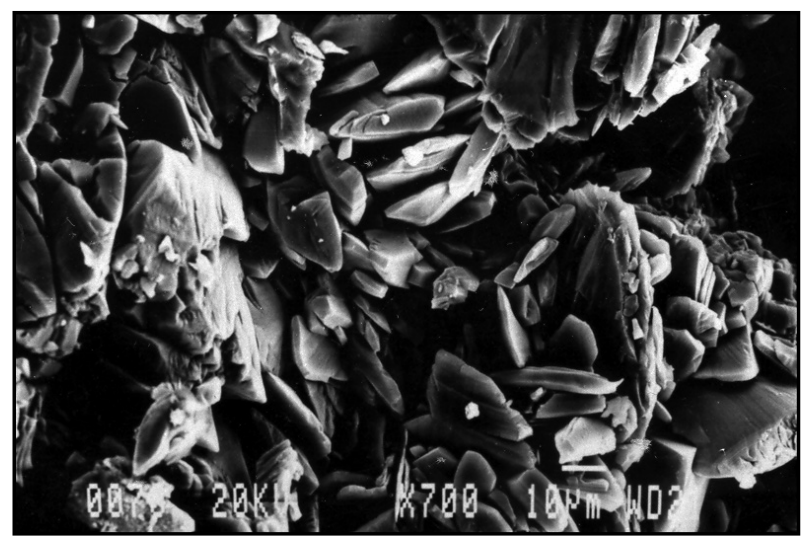

Figura 1. Fotografía obtenida con MEB de cristales de yeso presentes en una muestra de plaqueta de la Catedral de Santiago de Compostela. Figure 1. SEM micrograph of gypsum crystals in a plaquette sample from the Santiago de Compostela Cathedral.

Tabla 2 / Table 2

Resultados del análisis de difracción de rayos X. Los resultados son semicuantitativos e indican las cantidades relativas de cada mineral en las muestras.

$X$-ray diffraction finding. (semi-quantitative, indicating the relative quantities of each mineral in each sample).

\begin{tabular}{|c|c|c|c|c|c|c|c|}
\hline Muestra / Sample & $\mathbf{Q}$ & $\mathbf{F}$ & M & $\mathbf{K}$ & G & $\mathbf{C}$ & $\mathrm{OCa} / \mathrm{SO}_{3}$ \\
\hline \multicolumn{8}{|c|}{ Catedral de Santiago / Santiago Cathedral } \\
\hline Placa / Plaques 1 (40 cm) & ++++ & +++ & ++ & $\operatorname{Tr}$ & + & - & \\
\hline Placa / Plaques $2(70 \mathrm{~cm})$ & ++++ & +++ & ++ & - & ++ & - & \\
\hline Placa / Plaques $3(105 \mathrm{~cm})$ & ++++ & +++ & ++ & $\operatorname{Tr}$ & + & - & \\
\hline Mortero / Mortar 1 & +++ & + & + & $\operatorname{Tr}$ & + & ++++ & 30,0 \\
\hline Mortero / Mortar 2 & +++ & + & + & $\operatorname{Tr}$ & ++ & +++ & 6,7 \\
\hline \multicolumn{8}{|c|}{ Iglesia de Salomé / Salome Church } \\
\hline Placa / Plaques $1(70 \mathrm{~cm})(0-5 \mathrm{~mm}$ depth $)$ & ++++ & +++ & ++ & - & ++ & & \\
\hline Placa / Plaques $2(80 \mathrm{~cm})$ & ++++ & +++ & ++ & - & ++ & & \\
\hline Placa / Plaques $3(140 \mathrm{~cm})$ & ++++ & +++ & ++ & - & - & & \\
\hline Placa / Plaques $4(150 \mathrm{~cm})$ & ++++ & +++ & ++ & + & - & & \\
\hline Mortero / Mortar 1 & +++ & ++ & + & - & ++ & ++ & 10,7 \\
\hline Mortero / Mortar 2 & +++ & ++ & + & - & ++ & + & 0,7 \\
\hline Mortero / Mortar 3 & +++ & ++ & + & + & ++ & + & 0,7 \\
\hline \multicolumn{8}{|c|}{ Monasterio de S. Martín Pinario / S. Martín Pinario Monastery } \\
\hline Placa / Plaques $1(15 \mathrm{~cm})$ & ++++ & +++ & + & - & - & $\mathrm{Tr}$ & \\
\hline Placa / Plaques $2(45 \mathrm{~cm})$ & ++++ & +++ & + & - & - & - & \\
\hline Placa / Plaques $3(85 \mathrm{~cm})$ & ++++ & +++ & + & - & - & - & \\
\hline Placa / Plaques $4(130 \mathrm{~cm})$ & ++++ & +++ & + & - & - & - & \\
\hline Placa / Plaques 5 (38 cm) (0-3 mm depth) & ++++ & +++ & + & + & - & - & \\
\hline Placa / Plaques 5 (38 cm) (3-9 mm depth) & ++++ & +++ & ++ & + & - & - & \\
\hline Placa / Plaques 5 (38 cm) (9-15 mm depth) & ++++ & +++ & ++ & + & - & - & \\
\hline Placa / Plaques 5 (38 cm) (15-21 mm depth) & ++++ & +++ & ++ & + & - & - & \\
\hline Mortero / Mortar 1 & ++++ & ++ & + & - & + & +++ & \\
\hline Mortero / Mortar 2 & ++++ & ++ & + & - & - & +++ & \\
\hline
\end{tabular}

Q: cuarzo/ quartz, F: feldespatos/ feldspars, M: micas, K: caolinita/ kaolinite, G: yeso/ gypsum, C: calcite/ calcite. (++++: $>50 \%$; +++: $30-50 \%$; ++: 30$10 \%$; +: 10-3\%; tr:<3\%; -: not detected).

La iglesia de Santa María Salomé es una iglesia románica del siglo XII situada en el casco antiguo de Santiago de Compostela. En la pared orientada hacia el norte la piedra está muy deteriorada presentando profusión de placas y plaquetas, sobre todo en la parte inferior hasta
The church of Santa María Salomé is a romanesque church from the XII century, situated in the old part of the city of Santiago de Compostela. The stone on the north-facing wall is highly deteriorated and has numerous plaques and plaquettes, particularly on the 
una altura de dos metros aproximadamente. En algunos lugares donde las placas o plaquetas se han caído se puede ver que la piedra por debajo de ellas está muy desagregada. En la primera hilada de sillares, la que está en contacto con el suelo, una pátina negra aparentemente de naturaleza biológica recubre la totalidad de la superficie, de modo que no se puede ver el estado de la piedra, pero aparentemente está más integra, al menos no está desplacada (15).

En esta pared se tomaron cuatro muestras de plaquetas a alturas crecientes en el muro; por debajo de la plaqueta situada a menor altura, se tomaron dos muestras sucesivas en profundidad (hasta $1,7 \mathrm{~cm}$ ). Además se recogieron tres muestras de mortero de juntas.

En los análisis de las sales solubles extraídas de las muestras de piedra (Tabla 1) se cuantificaron porcentajes realmente elevados de sulfato y de nitrato, según los casos, y también de calcio, cuyos mayores contenidos coinciden con los mayores contenidos de sulfato. En el caso de las muestras tomadas a diferentes profundidades en la pared, cuando se representan los porcentajes de $\mathrm{Ca}^{2+}$ y $\mathrm{SO}_{4}{ }^{2-}$ frente a la profundidad en mm (Figura 2), se puede ver que ambos iones muestran la misma tendencia y que se incrementan en el segundo nivel, justo por debajo de la plaqueta. Esto significa que el yeso está presente en esta área, hecho que pudo ser confirmado con la observación al MEB. En algunos lugares el yeso puede verse incluso a simple vista por debajo de las plaquetas recién desprendidas.

En cuanto a las muestras de mortero, los análisis por difracción de rayos $\mathrm{X}$ indicaron que el yeso es abundante en todas ellas. De los valores de la relación $\mathrm{OCa} / \mathrm{SO}_{3}$ se deduce que en los morteros 2 y 3 el aglomerante es casi exclusivamente yeso, mientras que en el $n^{0} 1$ hay una mayor proporción de cal. Esta variabilidad de composición en morteros de la misma pared no es extraña y lower part of the wall, up to a height of approximately two metres. The plaques and plaquettes have fallen off in some places, revealing the highly disaggregated stone below. The first course of ashlars, which is in contact with the ground, is almost entirely covered by a black patina of apparently biological nature, and the state of the stone cannot be clearly established, although it is apparently whole, and there appear to be no detachments (15).

Four plaquette samples were taken at different heights on the wall; below the highest plaquette, two samples were taken from successive depths (to $1.7 \mathrm{~cm}$ ). Three samples of joint mortar were also obtained.

The analysis of the soluble salts extracted from the stone samples (Table 1) revealed a high content of sulphate and nitrate, and also of calcium, the highest content of which coincided with the highest content of sulphate. For the samples taken from different depths of the wall, plots of the percentages of $\mathrm{Ca}^{2+}$ and $\mathrm{SO}_{4}{ }^{2-}$ against the depth in $\mathrm{mm}$ (Figure 2), show that both ions display the same tendency to increase at the second depth, just below the plaquette. This means that gypsum is present in this area, a finding that was confirmed by the SEM observations. In some sites, the gypsum can even be visually observed below the recently detached plaquettes.

As regards the mortar samples, the $X$-ray diffraction analyses indicated abundant amounts of gypsum in all of the samples. From the values of the $\mathrm{CaO} / \mathrm{SO}_{3}$ ratio, we deduced that in mortars 2 and 3 the binder consisted almost entirely of gypsum, whereas in mortar no 1 there was a greater proportion of lime. This variation in the composition of the mortar in the same wall is not

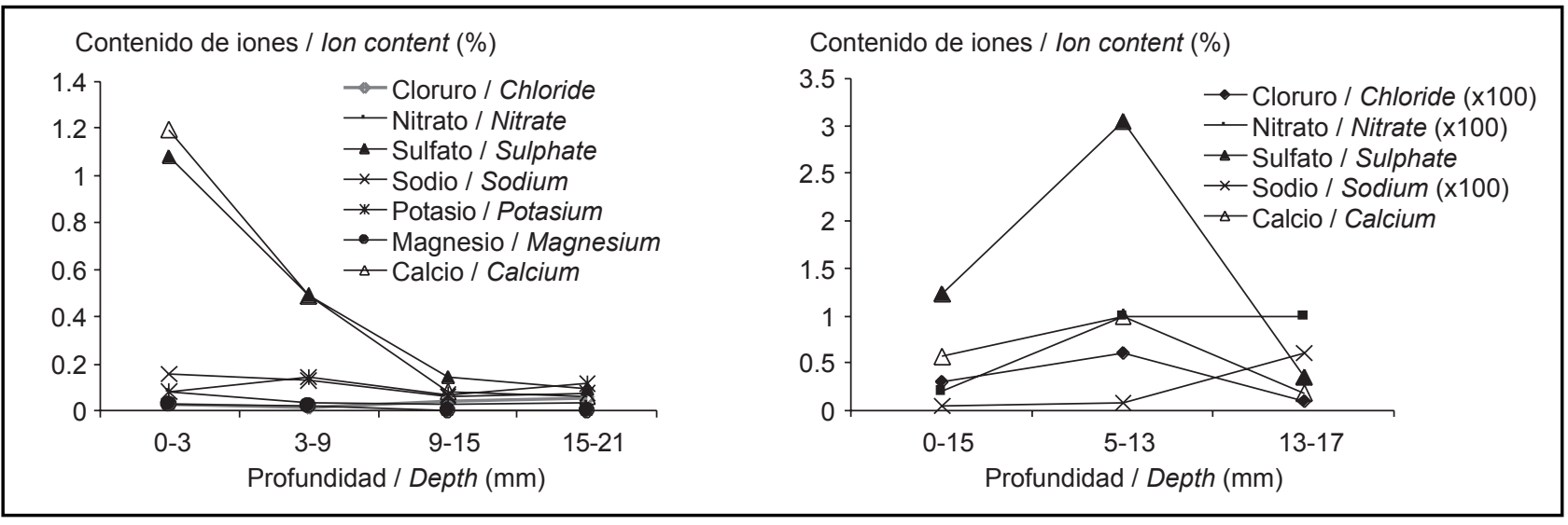

Figura 2. Contenido de iones en las muestras tomadas a distintas profundidades en el Monasterio de San Martín Pinario (izquierda) y en la Iglesia de Salomé (derecha).

Figure 2. Ion contents of samples taken in depth in S. Martín Pinario monastery (left) and Salomé church (right). 
se explica por el hecho de que se hayan llevado a cabo reparaciones de las juntas en diferentes momentos utilizando diferentes argamasas.

El conjunto monumental formado por el monasterio y la iglesia de San Martín Pinario constituye un magnífico ejemplo de las arquitecturas barroca y neoclásica de Santiago de Compostela. En uno de los claustros del monasterio, en la pared de fondo de los corredores, el proceso de desplacado del granito es muy evidente, especialmente en la pared que mira al norte (16). En esta pared se recogieron cinco muestras de placas a diferentes alturas. Además, fue extraído un sillar de la segunda hilada (a $38 \mathrm{~cm}$ de altura desde el suelo) y en este sillar se tomaron muestras a profundidades crecientes por debajo de la placa, hasta 2,1 cm. Por otra parte, se tomaron dos muestras de mortero: uno de juntas entre sillares y otro de la parte de atrás del sillar que se sacó del muro.

En los extractos acuosos de las muestras rocosas los iones más abundantes (Tabla 1) son el calcio y el sulfato. Los datos correspondientes a las muestras tomadas a diferentes profundidades en el sillar extraído del muro indican que ambos iones son más abundantes en la placa y van decreciendo a medida que aumenta la distancia a la superficie (Figura 2).

Los análisis por difracción de rayos $\mathrm{X}$ de las muestras de los morteros demostraron que sus principales componentes son cuarzo y calcita, tanto en el mortero de juntas como en el tomado en la parte de atrás del sillar extraído, pero el primero (mortero 1) posee además una cantidad apreciable de yeso. Dado que el yeso se encontró en el mortero de juntas, expuesto al ambiente, y no en el mortero de la parte de atrás del sillar, que por tanto está oculto, se podría pensar que el yeso se hubiera formado por sulfatación de la cal en las juntas. A este respecto hay que tener en cuenta por una parte que se trata de un muro situado en un claustro, por tanto protegido de la deposición atmosférica y, por otra parte, los bajos niveles de contaminación atmosférica de Santiago (en el año 2007 y en los seis años anteriores no se superaron los valores guía y límite para este gas, ver (17)). Por tanto, la hipótesis más probable es que el yeso haya sido añadido a la argamasa en el momento de su elaboración.

También se analizó un conjunto de muestras tomadas en la fachada de la iglesia de San Martín Pinario, adyacente al monasterio. En este caso se estudió la parte inferior de la fachada, alrededor de la puerta principal. En esta área la piedra está muy deteriorada presentando placas, plaquetas, escamas y, en algunos lugares, un depósito superficial blanquecino bastante duro y coherente. Se tomaron muestras de separaciones superficiales y de uno de los depósitos y también se tomó muestra de un mortero de juntas. unusual and can be attributed to the repairs made at different times and with different mortars.

The Monastery and the Church of San Martín Pinario constitute a magnificent example of the baroque and neoclassic architecture of Santiago de Compostela. In one of the cloisters of the monastery, the process of plaque shedding is very evident on the walls of the corridors, especially on the north-facing wall (16). Five samples of plaques were taken from different heights on this wall. An ashlar was also extracted from the second course (at a height of $38 \mathrm{~cm}$ from the ground) and in this ashlar, samples were taken at different depths below the plaque, to a depth a $2.1 \mathrm{~cm}$. Mortar samples were also obtained: one from a joint between two ashlars, and another from the back of the ashlar extracted from the wall.

The most abundant ions in the aqueous extracts of the stone samples were calcium and sulphate (Table 1). The data corresponding to the samples taken at different depths from the ashlar extracted from the wall indicated that both ions were more abundant in the plaque and decreased in abundance with increasing distance from the surface (Figure 2).

The X-ray diffraction analysis of the mortar samples revealed that the main components were quartz and calcite, in both the joint mortar and in the mortar from the extracted ashlar, but that the first (mortar 1) also contained an appreciable amount of gypsum. Given that gypsum is present in the joint mortar exposed to the environment, and not in the mortar from the back part of the ashlar, and which is therefore not exposed, the gypsum may have been formed by sulphation of the lime in the joints. It must be taken into account that the wall is situated in a cloister and is therefore protected from atmospheric deposition, and also that the levels of atmospheric contamination in Santiago are low (in 2007 and in the six years before, the levels of $\mathrm{SO}_{2}$ did not surpass the acceptable limits (17)). Therefore the most likely hypothesis is that gypsum was added during preparation of the mortar.

A set of samples from the facade of the church of San Martín Pinario, adjacent to the monastery, was also analysed. In this case the lower part of the facade around the main door was studied. The stone is highly deteriorated in this area, and there are plaques, plaquettes and scales, and in some places a rather hard, whitish superficial deposit. Samples of superficial detachments were collected along with one sample of the deposits and one of the joint mortar. 
En las muestras de separaciones superficiales (Tabla 1) el ión sulfato es el más abundante, al igual que ocurre en los morteros en donde, además, hay que tener en cuenta el nitrato. La concentración de sulfato de los depósitos es muy llamativa. En una de las separaciones superficiales, la escama número 2, el sulfato está presente en una cantidad muy elevada pero no se encuentra una cantidad equivalente de ningún catión que pueda explicar la formación de un precipitado salino de sulfato; en todas las muestras recogidas en esta fachada, las correlaciones entre el sulfato y los cationes determinados son muy pobres (no se obtienen coeficientes de regresión mayores de 0,5 ) por lo que, quizás, cierta cantidad del sulfato presente en estas muestras haya sido aportado a la roca en forma de una sal cuyo catión no ha sido determinado o proceda de la deposición atmosférica. Sin embargo, parte de este sulfato sí está formando yeso, tal como lo revela la difracción de rayos $X$ (Figura 3 ), mediante la cual se identifica en estos depósitos calcita y yeso, siendo este último el componente mayoritario. Estos datos nos inducen a pensar que los depósitos son restos de bases de pinturas o de antiguos revestimientos hechos con yeso y quizás otros sulfatos. En cuanto al mortero, éste está formado por arena granítica y calcita; en él no se identificó yeso.

El cuarto caso de estudio presentado en este artículo, es un grupo escultórico que se encuentra en la basílica de Santa María la Mayor de Pontevedra (siglo XVI), una joya de la arquitectura gótica de Galicia. Se trata de un bajorrelieve en el que se representan escenas bíblicas que está situado en el interior de la iglesia, en la cara interna de la fachada principal. El estado de conservación de las esculturas era muy deficiente presentando diversas formas de alteración: manchas de humedad, áreas ennegrecidas, eflorescencias salinas, depósitos endurecidos y desagregación granular.
Sulphate was the most abundant ion in the samples of superficial detachments, (Table 1), as well as in the mortar, in which nitrate was also present. There was also a high concentration of sulphate in the deposits. In the superficial detachments, in scale $n^{0} 2$, sulphate was also present in a high quantity, but there was not an equivalent amount of any cation that could explain the formation of a saline precipitate of sulphate; in all the samples collected from this facade, the correlations between sulphate and the cations were very low (no regression coefficients $>0.5$ were obtained) and therefore it is possible that some of the sulphate present in these samples originated from the stone, in the form of a salt the cation of which was either not determined or originated from atmospheric deposition. However, some of this sulphate forms gypsum, as revealed by the $X$-ray diffraction analysis (Figure 3), which enabled identification of calcite and gypsum in these deposits, with the latter the predominant component. These data lead us to believe that the deposits are remains of ancient paints or plasters made of gypsum and perhaps other sulphates. The mortar was composed of granitic sand and calcite; no gypsum was found in the mortar sample.

The fourth case studied was a sculptured group in the church of Santa María la Mayor de Pontevedra (XVI century), a fine example of the gothic architecture in Galicia. The sculpture is a bas-relief representing biblical scenes, and is situated inside the church, on the inner face of the principal facade. The sculptures are in a poor state of conservation and several type of weathering can be observed: damp patches, blackened areas, saline efflorescences, hard deposits and granular disaggregation.

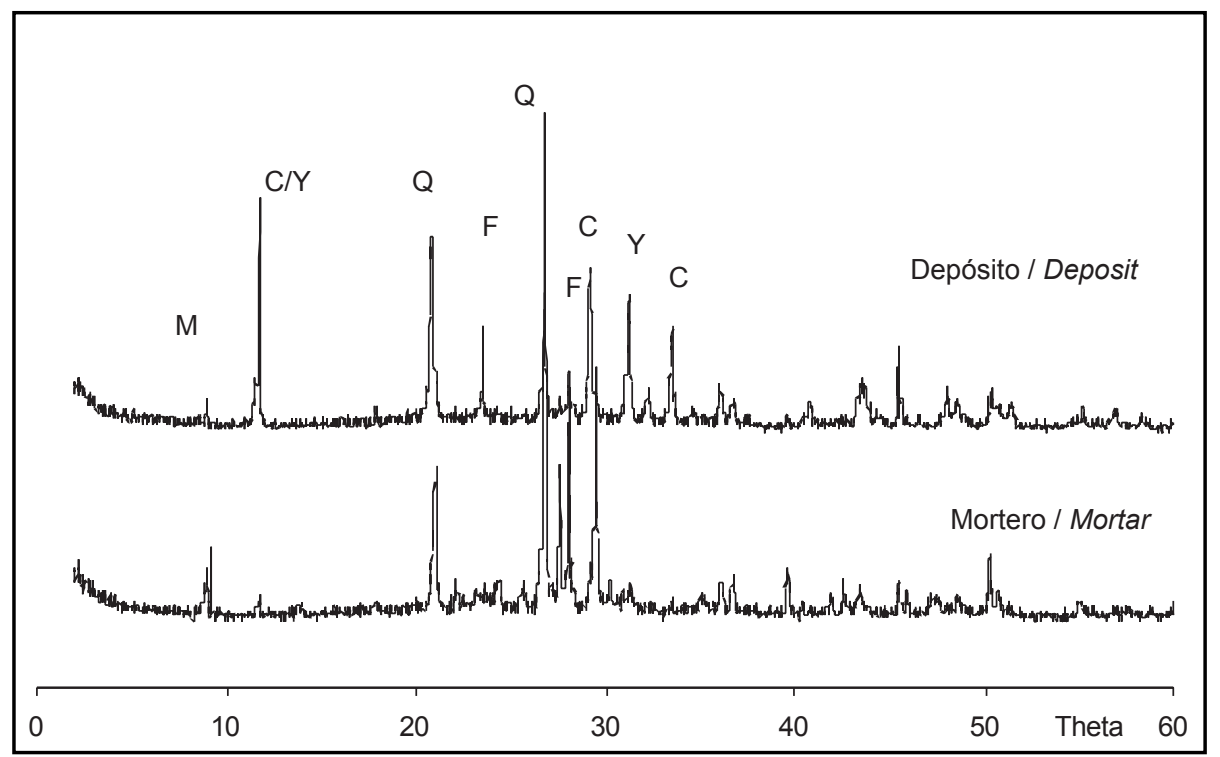

Figura 3. Difractogramas de rayos $X$ de las muestras de mortero y depósito tomados en la fachada de la iglesia de S. Martín Pinario Figure 3. X-ray diffractograms of mortar and deposit samples taken from the façade of S. Martín Pinario. 
Se analizaron muestras de arena desprendida de las áreas más desagregadas, muestras de depósitos y de morteros de juntas. El contenido de iones solubilizados en las muestras de arena son bastante bajos comparativamente a las muestras tomadas en otros monumentos; ninguno de los iones determinados se encuentra en cantidad significativamente mayor que los demás. Resultados similares se encontraron en otros casos de estudio y fueron relacionados con el desprendimiento de los granos minerales debido a la descohesión de la roca provocada por el incremento de tamaño que experimentan las fisuras al cristalizar las sales entre los granos minerales. Al mismo tiempo que caen los granos lo hacen las sales que habían cristalizado sobre ellos, de ahí que paradójicamente muchas veces las partes más arenizadas presentan bajos contenidos de sales.

El contenido de iones solubilizados fue moderadamente más alto en las muestras de morteros, y mucho más en las muestras de depósitos, siendo los sulfatos en estos dos tipos de muestra los iones más abundantes. En el conjunto de todas las muestras de esta iglesia, y a pesar del bajo contenido de iones en las muestras de naturaleza rocosa, se han obtenido correlaciones entre sulfato y el calcio, y el sulfato y el magnesio muy buenas $(r=0,98$ para ambos para una $p<0,059)$.

En cuanto al análisis por difracción de rayos $X$, en las muestras rocosas sólo se identificaron los minerales propios del granito; sin embargo por las correlaciones obtenidas entre el sulfato y el calcio creeremos muy probable la existencia de yeso cristalizado en los poros de la roca pero en una cantidad tan pequeña que esté por debajo del límite de detección de la técnica de difracción de
Samples of sand shed from the most deteriorated areas, of deposits and of joint mortar were analysed. The soluble ion content in the sand samples was relatively low compared with samples from other monuments; none of the ions determined were present in significantly higher amounts than the others. Similar results were found in other cases and were attributed to the detachment of mineral grains due to a loss of cohesion in the stone, caused by an increase in the size of the fissures as the salts between the mineral grains crystallize. The crystallized salts are shed at the same time as the mineral grains and therefore paradoxically, the sandiest parts often have the lowest salt contents.

The content of dissolved ions was moderately higher in the mortar samples, and much higher in the deposits, and sulphate was the predominant ion in both types of samples. Very good correlations between sulphate and calcium and between sulphate and magnesium were obtained in the entire set of samples from this church ( $r=0.98$ for both, $p<0.059)$, despite the low content of ions in the stone samples.

The X-ray diffraction analysis only revealed granite minerals; however, the high correlations between sulphate and calcium indicate the probable existence of crystallized gypsum in the rock pores, but in such small quantities that they are below the limit of detection of the $X$-ray diffraction technique. Granite minerals were also identified in the mortar samples, as the aggregate,

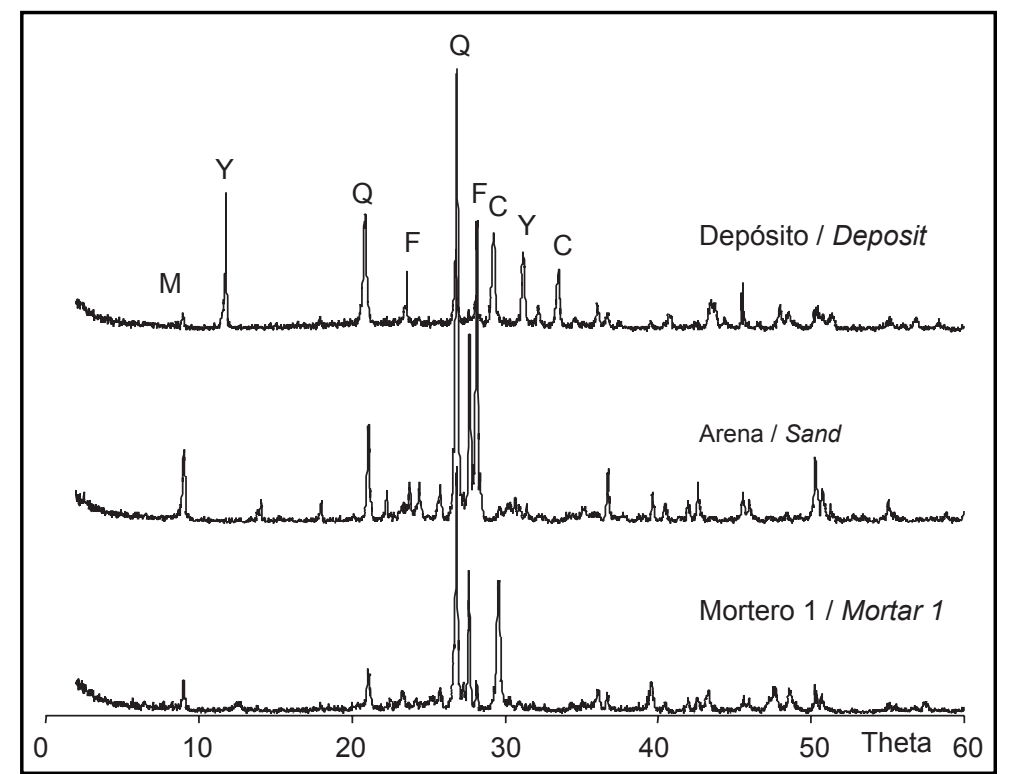

Figura 4. Difractogramas de rayos $X$ de las muestras tomadas en Sta. María de Pontevedra. Figure 4. X-ray diffractograms of samples taken from St. María de Pontevedra. 
rayos $\mathrm{X}$. En los morteros se identificaron también los minerales esenciales del granito, que constituyen el árido, y calcita como aglomerante. Finalmente, en las muestras de depósitos se identificó calcita y, sobre todo, yeso (Figura 4). El hecho de que los depósitos que se encuentran sobre las esculturas sean fundamentalmente de yeso, el cual, sin embargo, no aparece en los morteros de juntas, nos lleva a la convicción de que estos depósitos son restos de la base de antiguas policromías.

\section{DISCUSIÓN Y CONCLUSIONES}

En este trabajo se presentan los datos correspondientes a cuatro edificios representativos del patrimonio monumental de Galicia pero las conclusiones obtenidas son apoyadas por otros muchos casos estudiados en el noroeste peninsular (Galicia y norte de Portugal) (11).

En lo que se refiere al origen del yeso encontrado en la piedra, son varias las explicaciones posibles. La primera es que el yeso proceda de antiguos revestimientos. En las partes esculpidas de los monumentos esto parece indudable dado que en muchos casos se conservan restos de cal, yeso o ambos compuestos, que con toda probabilidad constituían la base de policromías. Pero también muchos paramentos lisos, sin esculpir, estuvieron pintados en otras épocas; en varias interesantes revisiones sobre este tema (18-19) se dice que los estucados de yeso eran comunes en los monumentos europeos en Ios siglos XVI-XVIII. El granito es una piedra polimineral, considerada poco noble como material arquitectónico y escultórico en épocas antiguas, por lo que se recubría con revestimientos, enlucidos o policromías. En un estudio reciente sobre pátinas negras desarrolladas sobre rocas graníticas (20), se encontró que en las ciudades de Santiago y La Coruña la mayoría de las pátinas poseen yeso como principal componente, tanto las que corresponden a monumentos como las que se encuentran en casas particulares sin ningún elemento escultórico; descartándose la procedencia de este mineral por contaminación atmosférica, se llegó a la conclusión de que, en estos casos, las pátinas se formaron a partir de antiguos revestimientos de las paredes que se fueron degradando, ensuciando y colonizando por microorganismos.

La segunda posibilidad es que el yeso proceda de los morteros de juntas. Este origen fue propuesto y demostrado en edificios de Dublín construidos con rocas graníticas (21-22). También en los edificios graníticos de Galicia en paredes que nunca estuvieron pintadas ésta es la explicación más plausible. En este caso caben otras dos opciones: que los morteros fuesen originariamente mixtos, de cal y yeso, como es el caso de la mayoría de los ejemplos presentados en este trabajo, o que el yeso se hubiera formado posteriormente por sulfatación de la and calcite as the binder. Finally, calcite and particularly gypsum, were identified in the samples of deposits (Figure 4). The fact that the deposits on the sculptures were essentially constituted of gypsum, which was not found in the joint mortars, leads us to conclude that these deposits are the remains of ancient paintwork (polychrome decoration).

\section{DISCUSSION AND CONCLUSIONS}

The data corresponding to four buildings representative of the monumental heritage of Galicia are presented, although the conclusions are supported by many other cases studied in the northwest Iberian Peninsula (Galicia and northern Portugal) (11).

As regards the origin of the gypsum in the stone, there are several possible explanations. The first is that the gypsum originates from ancient wall coverings. This is undoubtedly the case in the sculptured parts of the monuments as remains of lime, gypsum or both compounds were found in many samples, and they were probably components of the paints used. Moreover, many plain unsculptured walls were often painted in past eras; in various interesting reviews of this topic (18-19) it is reported that gypsum stuccos were common in European monuments in the XVI-XVIII centuries. Granite is a polymineralic rock, and was not considered sufficiently noble for use in monuments and sculptures in ancient times, and was therefore covered with plasterworks and paintings. In a recent study of the black patinas developed on granite rocks (20), it was found that in the cities of Santiago and La Coruña most of the patinas contain gypsum as the principal component, both on monuments and on private houses with no ornamental features; the possibility that this mineral originated from atmospheric contamination was discounted, and it was concluded that, in these cases, the patinas formed from the ancient wall coverings, which became degraded, dirty and colonized by microorganisms.

The second possibility is that the gypsum originates from joint mortars. This origin was suggested and demonstrated in buildings in Dublin constructed from granite (21-22). This is the most plausible explanation in the case of the buildings in Galicia that have never been painted. In the latter case there are two further possibilities: that the mortars were originally mixtures of lime and gypsum, as in most of the examples given in the present study, or that the gypsum formed posteriorly as a result of sulphation of lime. It appears that gypsum 
cal. Parece que la adición de yeso a las argamasas utilizadas para la reparación de juntas era común porque el yeso las hace más plásticas y fáciles de trabajar.

Pero la posibilidad de la sulfatación no se puede descartar de manera absoluta, incluso en ambientes con baja contaminación por $\mathrm{SO}_{2}$ como son los ambientes en los que se encuentran los edificios estudiados en este trabajo; algunos autores sostienen (23) que la velocidad de deposición de $\mathrm{SO}_{2}$ es más rápida cuanto más bajos son sus contenidos en la atmósfera, si bien estos estudios se realizaron sobre rocas de naturaleza carbonatada y, como es sabido (24), este tipo de rocas son muy reactivas frente a este proceso. Sin embargo, en el caso de rocas graníticas, se ha constatado que sí es posible la sulfatación en ambientes poco contaminados: en un estudio específico (25-26) se sometieron probetas de granito unidas con mortero de cal a una atmósfera con una concentración de $\mathrm{SO}_{2}$ equivalente en atmósfera a 80 $\mu \mathrm{g} / \mathrm{m}^{3}$ (la concentración más elevada que se dio en el año de ese estudio en Santiago de Compostela, ver (17)); al poco tiempo, y siempre que se suministrase agua, se constató la precipitación de yeso en la roca, si bien, en todos los casos, la sulfatación se produjo sobre la superficie de los morteros, emigrando el yeso desde éstos al interior de la roca.

Hay otros procesos que deben ser tenidos en cuenta a la hora de investigar los orígenes del yeso. La sulfatación del granito de forma similar a como ocurre en las rocas calizas se considera muy improbable dado su bajo contenido en calcio, sobre todo calcio de fácil liberación, y a la baja reactividad de este tipo de rocas a la deposición de $\mathrm{SO}_{2}$. Los únicos minerales del granito que poseen calcio son las plagioclasas que, además, en el caso de los granitos gallegos, son fundamentalmente albíticas (más ricas en sodio que en calcio). Aun así, algunos autores, mediante MEB-EDAX, han constatado la formación puntual de yeso por sulfatación del calcio liberado de las plagioclasas (27). Otros autores (28), por medio de la microscopía Raman, detectaron también cristales de yeso en un granito colonizado por líquenes así como en su propio talo y concluyeron que estos organismos, debido a su capacidad para acumular calcio y azufre, habían promovido la formación del mineral.

Sin embargo parece obvio que la contribución de estos procesos es insignificante y muy puntual, de manera que de ningún modo justificarían las cantidades notables de yeso que aparecen en algunas muestras. Así pues, consideramos que el yeso encontrado en los monumentos graníticos procede fundamentalmente de las argamasas.

Ya sea a partir de las juntas o de los revestimientos superficiales, el yeso se disuelve y los iones sulfato y calcio penetran en la piedra (11). El agua necesaria para la was commonly added to mortar used to repair joints because it makes the mortar more flexible and easy to work with.

However, the possibility that sulphation occurred cannot be totally discounted, even in environments with low levels of $\mathrm{SO}_{2}$, such as those considered in the present study; some authors (23) sustain that the rate of deposition of $\mathrm{SO}_{2}$ is faster at low atmospheric levels, although the corresponding studies were carried out on carbonaceous rocks and it is known that these types of rock are highly reactive to this process (24). However, it has been shown that sulphation of granite rock is possible in environments with low levels of contamination. In one specific study (25-26) granite specimens bound with lime mortar were subjected to an atmosphere containing the equivalent of $80 \mu g \mathrm{SO}_{2} / \mathrm{m}^{3}$ (the highest concentration reported in the year of the study in Santiago de Compostela, see 17); when water was supplied, gypsum precipitated in the stone within a short time, although in all cases the sulphation occurred on the surface of the mortar and the gypsum emigrated to the interior of the stone.

Other processes must be taken into account when investigating the origins of the gypsum. Sulphation of granite is considered unlikely to occur in the same way as in limestone rocks, given the low content of calcium (particularly readily available calcium) in the former and the low reactivity of this type of rock to deposition of $\mathrm{SO}_{2}$. Plagioclases are the only minerals in granite that contain calcium (but even in the considered granites they are richer in sodium than in calcium). Even so, some authors have shown, by MEB-EDAX, that formation of gypsum occurs by sulphation of the calcium released from plagioclases (27). Other authors (28) have detected crystals of gypsum in granite colonized by lichens, as well as in the lichen thalli, by Raman spectroscopy, and concluded that the capacity of these organisms to accumulate calcium and sulphur leads to formation of the mineral.

However, obviously the contribution of these processes is not highly significant and occurs only in specific points, and does not explain the rather large quantities of gypsum that appear in some samples in the present study. We therefore believe that mortars are the main supplier of the gypsum found in granite monuments.

Whether the gypsum originates from the joints or from the plasters, it dissolves and the sulphate and calcium ions penetrate the stone (11). The water required for 
disolución y movilización de los iones a través de la pared puede entrar por diferentes vías. Puesto que las separaciones superficiales se encuentran sobre todo en las partes bajas de las paredes, incluso en aquéllas que están protegidas de la lluvia, como en claustros o soportales, parece obvio que el ascenso por capilaridad desde el suelo o subsuelo es la vía principal de entrada de agua, sin descartar el posible aporte por condensación (16).

Cuando la pared se seca el proceso de evaporación del agua genera el movimiento de las disoluciones hacia la superficie. Las disoluciones se van concentrando y comienzan a precipitar las sales en un orden de menor a mayor solubilidad. En esta situación el yeso es la sal que tiene más probabilidades de cristalizar debido a su solubilidad moderada mientras que otras sales más higroscópicas que se pudieran formar a partir de los iones presentes, permanecen en disolución dando a la pared un aspecto húmedo.

Todos los datos apoyan la idea de que las separaciones superficiales son generadas por la precipitación del yeso pero hay dos mecanismos posibles (11-12). El primero es que el yeso se vaya acumulando en la capa más superficial de los sillares la cual, precisamente por este motivo tiene un comportamiento físico-mecánico diferente al resto de la masa rocosa y acaba separándose. La otra posibilidad es que el yeso precipite a una cierta profundidad por debajo de la superficie ejerciendo una presión sobre las paredes de las fisuras y causando su apertura. Probablemente pueden darse los dos mecanismos, pues, en algunos casos, la mayor concentración de yeso se encuentra en las propias placas y, en otros, justo por debajo de ellas. En la mayor parte de los casos estudiados nos parece más factible el segundo (11). Esta idea se apoya en dos observaciones; la primera es que muchas veces las placas presentan una notable coherencia mientras que la roca por debajo de ellas está más descohesionada, y la segunda es que cuando se extrae una placa es frecuente ver el yeso formando subeflorescencias por debajo de ella.

\section{AGRADECIMIENTOS}

Este estudio fue parcialmente financiado por el Ministerio de Educación (Programa Ramón y Cajal) dissolution and mobilization of the ions through the stone may enter by different via. As surface detachments are mainly found on the lower parts of the walls, even in those protected from the rain, as in cloisters or porticos, it appears obvious that capillary rise is the main route of entry of water, although possible inputs from condensation should not be discounted (16).

When a wall dries, the process of evaporation generates movement of the solutions to the surface. These solutions become concentrated and the salts begin to precipitate in an order from lower to higher solubility. Gypsum is the salt most likely to precipitate because of its moderate solubility, whereas other more hygroscopic salts that may be formed from the ions present will remain in solution, giving the wall a damp appearance.

All of these data support the idea that superficial detachments are generated by precipitation of gypsum, although there are two possible mechanisms (11-12). The first is that the gypsum accumulates in the outermost layer of the ashlars, which therefore display different physical-mechanical behaviour than the rest of the rock mass and finally become separated from the rock. The other possibility is that the gypsum precipitates at a certain depth below the surface and exerts pressure on the walls of rock fissures causing them to open up. Both mechanisms probably occur because in some cases the highest concentrations of gypsum are found in the plaques themselves, and in other cases immediately below them. In most cases studied, the second mechanism appears most feasible (11). This is supported by two observations, firstly that the plaques are often cohesive, whereas the underlying rock is less so, and secondly, that when a plaque is removed, gypsum is often observed forming subefflorescences in the underlying area.

\section{ACKNOWLEDGEMENTS}

This study was partly funded by the Spanish Ministery of Education (Ramón y Cajal Programme)

\section{BIBLIOGRAFÍA / BIBLIOGRAPHY}

(1) Evans, I. S.: "Salt crystallisation and rock weathering: a review". Revue de Geomorphologie Dynamique, 1er année, no. 4 (1970), pp. 153-177.

(2) Arnold, A.; Zehnder, K.: "Salt weathering in monuments". Proc. I. Int. Symp. Conservation of Monuments in the Mediterranean Basin., F. Zezza (ed.), Hari (1989), pp. 31-58.

(3) Charola, A. E.: "Salts in the deterioration of porous materials: an overview". Journal of America Institute if Conservation 39 (2000), pp. 327-343.

(4) Doehne, E.; Selwitz, C. X.; Carson, D.; de Tagle A.: "Damage to monuments from the crystallization of mirabilite, thenardite and halite: mechanisms, environment and preventive possibilities". 11th Annual V.M. Goldschmidt Conference (2001). 
(5) Rodríguez-Navarro, C.; Doehne, E.; Sebastian, E.: "How does sodium sulfate crystallize? Implications for the decay and testing of building materials". Cem. Concr. Res. 30 (2000), 1527-1534. doi:10.1016/S0008-8846(00)00381-1

(6) Tsui, N.; Flatt, R.; Schere, G. W.: "Crystallization damage by sodium sulphate". J. Cultural Heritage 4 (2003), $109-115$. doi:10.1016/S1296-2074(03)00022-0

(7) Lazzarini, L.: "I graniti dei monumenti italiani ed il loro problemi di deterioramento". Bolletino d'Arte del Ministerio per I Beni Culturali e Ambientali, no 41/1987, 157-172.

(8) Esbert, R. M.: "Alteration of granite stone used in building construction". Materiales de Construcción, vol. 57, 288 (2007), pp. 77-89.

(9) Casal, M.; Silva, B; Delgado, J.: "Agents and forms of weathering in granitic rocks used in monuments". Proc. Europ. Symp. Science, Technology and European Cultural Heritage. N. S. Baer, C. Sabbioni and D. I. Sors (ed.), Bologna (1989), pp. 439-442.

(10) Alonso, F. J.; Vázquez, P.; Esbert, R. M.; Ordaz, J.: "Ornamental granite durability: evaluation of damage caused by salt cristalization"; Mater. Construcc., vol 58, no 289-290 (2008), pp. 191-201.

(11) Silva, B.; Rivas, T.; Prieto, B.: "Soluble salts in granitic monuments: origin and decay effects". Applied Study of Cultural Heritage and Clays. J. L. Pérez (ed.) (2003), pp. 113-130.

(12) Silva, B.; Rivas, T.; Prieto, B.; Delgado, J.: "A comparison of the mechanisms of plaque formation and sand disintegration in granite in historic buildings", Degradation and Conservation of granitic rocks in monuments. M. A. Vicente, J. Delgado, J. Acevedo (ed.), European Commission DG XIII, Bruselas (1996), pp. 269-274.

(13) Silva, B.; Rivas, T.; Prieto, B.: "Relation between type of soluble salt and decay forms in granitic coastal churches in Galicia (NW Spain)". European Commission Research Workshop Origin, Mechanisms and Effects of Salts on Degradation of Monuments in Marine and Continental Environments. Zezza (ed.). DGXII, Protection and Conservation of the European Cultural heritage, Bari (1996).Research report no 4, pp. 181-190.

(14) Silva, B.; Rivas, T.; Prieto, B.; Casal, M.; Guitián, F.: "Forms and factors of weathering in the Cathedral of Santiago de Compostela". Proceedings of VII International Congress on Deterioration and Conservation of Monuments in The Mediterranean Basin. Venecia (1994), pp. 743-748.

(15) Casal, M.; Delgado, J.; Silva, B.: "Construction materials and decay problems of Salome church in Santiago de Compostela", Proceeding of the VII Int. Congress on Deterioration and Conservation of Stone, vol. 1 (1992), pp. 3-11.

(16) Rivas, T.; Prieto, B.; Silva, B.: "Plaque-shedding by granite in the Monastery of San Martín Pinario (Santiago de Compostela, NW Spain)", Proceedings of the VII International Congress on Deterioration and Conservation of Monuments in the Mediterranean Basin, Venecia, Italia (1994), pp. 737-742.

(17) Sistema de Información Medioambiental de Galicia SIAM, Xunta de Galicia. Informe estadístico sobre calidad del aire, 2007. Accesible por Internet (http://aire.medioambiente.xunta.es/).

(18) Cabrera, J. M.: "Materiales de reparación: sus mecanismos de actuación y criterios de selección", Actas de las jornadas sobre restauración y conservación de monumentos, Madrid (1989), pp. 89-100.

(19) Cabrera, J. M.: "Contaminación y patrimonio. Punto de vista del restaurador", Actas del encuentro europeo sobre Patrimonio Histórico Artístico y contaminación, Madrid (1992), pp. 59-63.

(20) Prieto, B.; Aira, N.; Silva, B.: "Comparative study of dark patinas on outcrops and buildings", Sci. Tot. Env. 381 (2007), pp. 280289. doi:10.1016/j.scitotenv.2007.04.002

(21) O’Brien, P. F.; Bell, E.; Santamaría, S. P.; Boyland, P.; Cooper, T. P.: "Role of mortars in the decay of granite". Sci. Tot. Env. 167 (1995), 103-110. doi:10.1016/0048-9697(95)04573-J

(22) Cooper, T. P.; Dowding, P.; Lewis, J. O.; Mulvin, L.; O'Brien, P.; Olley, J.; O’Daly, G.: "Contribution of calcium from limestone and mortar to the decay of granite walling". Science, Technology and European Cultural Heritage. N.S. Baer, C. Sabbioni and A.I. Sors (eds.). Butterworth-Heineman, Oxford (1991), pp. 456-461.

(23) Wittenburg, C.; Dannecker, W.: "Salt enrichment in building stones by deposition of sulphur and nitrogen containing species from urban atmospheres". In: Proc. 3rd Int. Symp. on the Conservation of Monuments in the Mediterranean Basin. IGCMM (1994), pp. 179183.

(24) Furlan, V.; Girardet, F.: "Pollution atmospherique et reactivité des pierres". Proc. VII Int. Cong. Deterioration and Conservation of Stone, Delgado, Henriques and Telmo (eds.). Lisboa (1992) vol. 1, pp. 153-161.

(25) Rivas, T.; Prieto, B.; Silva; B.: "Gypsum formation in granitic rocks by dry deposition of sulphur dioxide". Proceedings of the IV Int. Symp. on the conservation of monuments in the Mediterranean Basin, Rhodes (1997), pp. 263-270.

(26) Rivas, T.; Prieto, B.; Silva, B.: "Artificial weathering tests of granitic rocks". Mater. Construcc., vol. 58, no 289-290 (2008), pp. 179189.

(27) Schiavon, N.; Chiavari, G.; Fabbri, D.; Schiavon, G.: "Microscopical and chemical analysis of black patinas on granite". Proceedings of the III Int. Symposium on the conservation of monuments in the Mediterranean Basin, Venice, Italy (1994), pp. 93-95.

(28) Prieto, B.; Seaward, M. R. D.; Edwards, H. G. M.; Rivas, T.; Silva, B.: "An FT-Ramman spectroscopic study of gypsum neoformation by lichens growing on granitic rocks". Spectrochimic. Acta. A., vol. 55 (1999), pp. 211-217. doi:10.1016/S1386-1425(98)00245-5 